\title{
The Composition of Numbers 32: A New Proposal*
}

\author{
Liane M. Marquis \\ The University of Chicago Divinity School \\ Imarquis@uchicago.edu
}

\begin{abstract}
This paper addresses the compositional history of the story of the apportionment of the Transjordan to the Reubenites and Gadites in Numbers 32. After a detailed study of the narrative difficulties within this chapter, it is argued that Numbers 32 contains two independent stories and a post-compilational insertion. Each of the two stories is then analyzed on its own terms and placed within its broader Pentateuchal context.
\end{abstract}

Keywords

Numbers, Pentateuch, documentary hypothesis

Numbers 32, the story of the apportionment of the Transjordan to the Reubenites and Gadites, has generally been understood as a composite text containing both priestly and non-priestly elements. ${ }^{1}$ Despite this broad consensus, there is virtually no agreement among scholars concerning the precise compositional history of this chapter. ${ }^{2}$ The different reconstructions that have been offered,

*) I would like to express my gratitude to Jeffrey Stackert and Simeon Chavel for their comments and suggestions on an earlier draft of this paper, and especially to Joel Baden for his invaluable support and wisdom, from which this paper and I have greatly benefitted.

1) A minority of scholars have argued for the literary unity of this chapter. See A. Kuenen, $A n$ Historical Inquiry into the Origin and Composition of the Hexateuch (London, 1886); J. Estlin Carpenter and G. Harford Battersby, The Hexateuch, According to the Revised Version, Vol. 2 (London, 1900); J. Milgrom, The JPS Torah Commentary: Numbers (Philadelphia, 2003). Ashley has argued for a primarily unified text with vv. 1-38 as one unit and vv. 39-42 comprising a later addition. T. R. Ashley, The Book of Numbers (NICOT; Grand Rapids, MI: Wm. B. Eerdmans Publishing Co., 1993), 605-6o6.

2) Beyond the documentary/supplementary divide, each of these scholars suggests a unique division of Numbers 32: J. Wellhausen, Die Composition des Hexateuchs und der historischen Bücher des alten Testaments (Berlin, 1889); W. E. Addis, The Documents of the Hexateuch Translated and Arranged in Chronological Order with Introduction and Notes, Vols. 1 \& 2 (London, 1892); 
however, do respond to basically the same narrative difficulties. Taking into account these commonly identified narrative difficulties, I will offer a literary analysis of Numbers 32 that does not initially presume or require commitment to any particular theory of the development of the Pentateuch. This analysis will be made by examining Numbers 32 on its own and looking at the contradictions inherent therein. After a close examination of these narrative inconsistencies, contradictions and doublets, I will argue that there are two distinct complete, coherent, and continuous narratives in Numbers 32 . I will also demonstrate that there is far less redactional activity than has been suggested in previous analyses and that none of the redactional activity in this chapter deviates from the compiler's conventional practices. ${ }^{3}$ Consistent with most studies of Numbers 32, I will demonstrate that vv. 7-15 are a secondary insertion from a different hand than either of the two narratives.

B. W. Bacon, The Triple Tradition of the Exodus: a Study of the Structure of the Later Pentateuchal Books, Reproducing the Sources of the Narrative, and Further Illustrating the Presence of Bibles within the Bible (Hartford, 1894); S. R. Driver, A Critical and Exegetical Commentary on Deuteronomy, 3rd ed. (International Critical Commentary 3; Edinburgh, 1902); G. B. Gray, A Critical and Exegetical Commentary on Numbers (ICC; New York, 1906); E. S. Brightman, The Sources of the Hexateuch (Oxford, 1948); M. Noth, Numbers: A Commentary (OTL; Nashville, 1969); S. Mittmann, Deuteronomium 1:1-6:3 Literarkritisch und traditionsgeschichtlich untersucht (Beiheft zur Zeitschrift für die alttestamentliche Wissenschatft 139) (Berlin, 1975); J. Licht, Perush 'al Sefer be-Midbar vol. 3 (Jerusalem, 1985); E. Blum, Studien zur Komposition des Pentateuch (Beiheft zur Zeitschrift für die alttestamentliche Wissenschatft) (Berlin, 1990); S. E. Loewenstamm, "The Settlement of Gad an Reuben as Related in Nu 32:1-38-Background and Composition," in idem From Babylon to Canaan: Studies in the Bible and its Oriental Background ( Jerusalem, 1992); N. Lohfink, Theology of the Pentateuch: Themes of Priestly Narrative and Deuteronomy (Minneapolis, 1994); J. Van Seters, The Life of Moses: The Yahwist as Historian in Exodus - Numbers (Nashville, 1994); H. Seebass, "Erwägungen zu Numeri 32:1-38," Journal of Biblical Literature 118, no 1 (1999): 33-48; B. Levine, Numbers 21-36: A New Translation with Introduction and Commentary (Anchor Yale Bible 4b; New Haven, 2000); L. Schmidt, "Die Ansiedlung von Ruben und Gad im Ostjordanland in Numeri 32,138," Zeitschrift für die Alttestamentliche Wissenschaft 114 (2002): 497-510; R. Achenbach, Die Vollendung der Tora: Studien zur Redactionsgeschichte des Numeribuches im Kontext von Hexateuch und Pentateuch, Beihefte zur Zeitschrift für Altorientalische und Biblische Rechtsgeschichte, vol. 3 (Wiesbaden, 2003); J. S. Baden, J, E, \& the Redaction of the Pentateuch (Forschungen zum Alten Testament) (Tübingen, 2009).

3) See Gray, Numbers, 426; Kuenen, Hexateuch, 101. Both of these scholars suggest that the compiler or a redactor is deviating from his usual practice of weaving two sources together in order to make up his own account based upon them. Baden also suggests overly complex redactional activity in this chapter (Redaction, 143-144). 


\section{Major Narrative Difficulties in Numbers 32}

There are three major narrative difficulties in Numbers 32 that preclude reading the text as a literary unity. These are discrepancies over 1) when the land east of the Jordan (the Transjordan) is given to the Reubenites and Gadites and by whom, 2) what consequence these two tribes will face if they do not help the Israelites inhabit Canaan, and 3 ) what the Israelite military formation looks like. There are a number of smaller narrative difficulties within this chapter, each of which will be addressed in turn, but these three major problems render Numbers 32 fundamentally unreadable as it stands in the canonical Pentateuch.

The first narrative problem is perhaps the most insurmountable. According to Numbers 32:33, Moses gives the Reubenites, Gadites, and the half tribe of Manasseh 4 the kingdoms of Sihon and $\mathrm{Og}$ while still outside the promised land. These territories were conquered by the Israelites in Numbers 21:31 and 21:35, respectively. In direct contradiction to v. 33 are vv. 20-22, in which Moses sets up a future condition for the two tribes: they may have the land they requested as a possession, but only after they have helped the rest of the Israelites subdue Canaan. Along these same lines, in vv. 28-30 Moses tells Eleazar, Joshua and the leaders of the tribes that they, not Moses, will be the ones to give the Transjordanian land to the Reubenites and Gadites after the conquest of Canaan.

A secondary complication arises from this first problem: is the Transjordanian land inhabitable or not? According to the narrative of Numbers 21, the Israelites not only conquer the Transjordan, they also settle in it. Regarding the וישב (ישוtes" ישראל בארץ האמרי (ישרי). Likewise, regarding the kingdom of Og, Num 21:35 states, "They took possession of his land" (ויירשו את ארצו). Logically enough, in Numbers 20-21, there is no mention of the cities of Sihon and Og being destroyed, only their inhabitants. This means that the Israelites should be living in the Transjordanian land in Numbers 32 . Yet this renders problematic the recurring notion in Numbers 32 that the Reubenites and Gadites will build (or rebuild) the cities and sheepfolds of this region $(32: 16,17,24,26,34-38)$; per Num 21, they were never destroyed. In another account of the conquest of the Transjordan in Numbers 31, we are told that the Israelites "destroyed by fire all the towns in which they [the Midianites] were settled, and their encampments" (31:10). That the Israelites would then have to rebuild the towns before inhabiting them is a logical consequence of this second Transjordanian conquest narrative. That being said, the idea that the Transjordanian cities have been destroyed and need to be rebuilt is at odds with 32:33, in which Moses gives to the Gadites and

4) The issue of the half-tribe of Manasseh will be dealt with in detail below. 
Reubenites "the land with its various cities." This assumption in 32:33 that cities exist already accords perfectly with the story of Numbers 21 , however, and is confirmed with the explicit mention of Sihon and Og in 32:33. It appears that we have two competing ideas in Numbers 32 : that the Israelites are already living in the Transjordan and have been since the conquest in Numbers 21, and that the Israelites have just conquered and completely destroyed the land in Numbers 31 and now have to rebuild it before they can inhabit it. 5

A second narrative problem arises regarding what will happen if the Reubenites and Gadites fail to help the Israelites gain possession of Canaan. In this case, according to v. 30, Moses instructs Eleazar, Joshua, and the leaders of the tribes to give them their holding not in the Transjordan as they have requested, but in the land of Canaan. In v. 23, by contrast, Moses tells the two tribes that if they do not do as they have said, then they will have sinned against Yahweh and their sin will "find them." ${ }^{6}$ No mention is made of the land itself or where the tribes will live. These two punishments need not necessarily be contradictory, but it is rather implausible that the divine punishment threatened in v. 23 turns out to be simply inheriting the land they were expected to inherit before they made their request at the beginning of Numbers 32 . Furthermore, the two different notions of when the Reubenites and Gadites are supposed to receive their land complicates any attempt to read vv. 23 and 30 as a single, two-part threat. It is difficult to believe that the Reubenites and Gadites could be given the land in the Transjordan before helping the Israelites gain possession of Canaan (v. 33) if the punishment for not helping is that they will not receive the land in the Transjordan (v. 30). ${ }^{7}$ Rather, it makes more sense to posit two

5) Contra Gray who argues that this chapter takes no account of Numbers $3^{1}$ (Numbers, 426). Budd argues that Numbers 32 presupposes and continues a "Yahwistic Transjordanian tradition" in Num 21:1-21:5, but he does not perceive the problem with the Reubenites and Gadites rebuilding cities and towns in Num 32:34-38 that were never destroyed in the earlier "Yahwistic" sections of this tradition. P. Budd, Numbers (Word Biblical Commentary 5; Nashville: Thomas Nelson Publishers, 1984), 341.

6) What, precisely, תמצא אתכם means is somewhat ambiguous. Clearly it is a 3 fs form and its subject can only be חטאתכם. What seems to be implied is that these tribes will suffer some kind of divine retribution if they fail to fight for the rest of the Israelites in Canaan. Lohfink suggests that this might be a reference to "Israel's original sin, the making of the golden calf" (Theology, 218). I might suggest that while he is headed in the right direction, the substance of this reference goes back to the original story in Exod 32:30-34 rather than Deuteronomy 9:16 and that it more plausibly refers to the explicit threat of the Israelites' sins being visited upon them in 32:34 and not the issue of the golden calf.

7) In an attempt to harmonize this seeming contradiction, ibn Ezra, commenting on v. 30, suggested that the Reubenites and Gadites would have to be carried by force across the Jordan into the land of Canaan to help subdue the land. 
distinct accounts of the apportioning of the Transjordan. In the first account, the two tribes receive the land from Moses before crossing the Jordan (v. 33); if they fail to cross the Jordan, they will have sinned against Yahweh and their sin will find them (v. 23). In the second account, the Reubenites and Gadites will receive the Transjordanian land after they help subdue Canaan (vv. 20-22); if they fail to do so, they will not be given the Transjordanian land, but will inherit a portion in Canaan; they won't receive what they have asked for (vv. $28-30){ }^{8}$

The final significant narrative problem in Numbers 32 has to do with the military formation of the Israelites when they cross the Jordan. In v. 17a, the two tribes promise "we will hasten to fight at the head of the Israelites (יפני בני ישראל (ישרי)." In v. 29, however, Moses tells Eleazar, Joshua and the tribal leaders that if the Gadites and Reubenites "cross over the Jordan equipped for

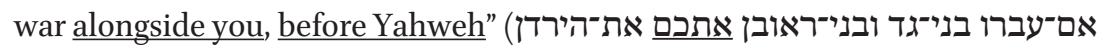
(כל־חלוץ למלחמה לפני יהוה), their request should be granted. Are the Reubenites and Gadites leading the charge, or are they simply joining it? The phrase לפני יהוה in v. 29 plays a significant role in this discussion. It appears throughout Numbers 32 as a descriptor of where and how the Reubenites and Gadites should fight (Num 32:20, 21, 22, 27, 29, 32). This phrase has been variously translated, ${ }^{9}$ but the plain meaning is the best rendering. When the Reubenites and Gadites fight אתכם... לפני יהוה, they are to fight in the midst of the Israelites and literally in front of Yahweh.

The image of the Gadites and Reubenites fighting אתכם... לפני יהוה, which is more fully portrayed in Numbers $2-4,{ }^{10}$ is different from the image of the Reubenites and Gadites fighting לפני בני ישראל (v. 17a). In v. 17a, the two tribes are described as promising to be at the head of all the Israelites leading them across the Jordan and into battle. The Reubenites and Gadites cannot be in front of the Israelites and behind the camp of Judah (among the Israelites) at the same time; the אתכם... of v. 29 thus cannot be not part of the same story as the לפני בני ישראל of v. 17 because they offer contradictory pictures of the Israelite battle formation.

8) While Seebass has correctly identified the narrative tension between v. 23 and v. 30 (in his analysis vv. 28-32), he has incorrectly concluded that one of the two texts must be secondary, in his opinion vv. 28-32. "Erwägungen," 38.

9) The most common translations are "at the instance of Yahweh" (JPS) and "before Yahweh" (NRSV, NJB, NASB, KJV, ESV).

10) In this passage, the dismantled Tabernacle, the abode of Yahweh, is at the very center of the military formation, surrounded on all sides by the Israelite tribes. The camp of Judah is told to lead the Israelites into battle (Num 2:9), and the camp of Reuben is assigned to march second, behind Judah and directly in front of the dismantled Tabernacle (Num 2:17). The tribe of Gad is listed as a subset of the camp of Reuben (Num 2:14). 
Thus far I have shown that there are three narrative issues necessitating the division of Numbers 32: who gives the land and when, the consequences for the Reubenites and Gadites should they fail to keep their promise, and the position of the two tribes in the military formation. In each of these three instances, two distinct perspectives have emerged. The first account-story A-claims that Gadites and Reubenites will lead the Israelites into battle, but only after they have been given the land that the Israelites have been living in since the conquest in Numbers 21. If they do not do so, they will have sinned against Yahweh. In the second account - story B-Moses demands that the Gadites and Reubenites fight alongside the Israelites and in front of Yahweh. Only after they do this will Eleazar and Joshua give them the land, which is currently completely destroyed and uninhabited (31:10). If they do not fulfill Moses' condition, they will inherit their portion in Canaan, not in the Transjordan.

\section{Literary Analysis}

Having separated these dual threads, it is now possible to follow them through the rest of Numbers 32. Turning first to vv. 20-23 and Moses' condition for the Reubenites and Gadites, it is possible to disentangle two separate iterations of this condition. On a structural level these verses contain three protases and three apodoses. In v. 23 the Reubenites and Gadites are told: "if you do not do thus (ואם לא תעשון כן), then you will have sinned against Yahweh and against Israel." The positive counterpoint to this negative condition can be found in v. 20aß: "if you do this thing" (אם תעשון את הדבר הזה), which continues in v. 22aß: "then you shall be clear before Yahweh and before Israel." Rather than having sinned, the Reubenites and Gadites will be נקיים, innocent." When these two sets of protases and apodoses are removed, a third pair remains. It begins in v. 2ob: "If you go to battle to fight before Yahweh." This conditional statement continues through v. 22a $\alpha$ and has its apodosis in v. 22b: "then this land will become your holding before Yahweh."12 As suggested above, this apodosis does not accord

11) The use of and as counterpoints has a precise parallel in Gen 20:5-6. There is a close

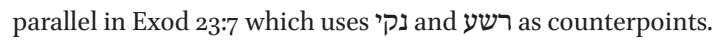

12) This use of לפני יהוה is not consistent with every other use of לפני יהוה in this chapter. Here it does not denote any sort of military context, but rather the fulfillment of a promise. The phrase appears four times in these two and a half verses. The first three times it is in reference to the military formation. This final time, it may well take on the meaning of "at the instance of Yahweh" (JPS) meaning something like "according to what Yahweh has ruled." This is a nice literary play on the phrase and connects well with v. 31 wherein the two tribes promise that they will do אשר דבר יהוה. At first glance it appears that v. 31 is the first mention of Yahweh commanding or speaking anything directly to the Reubenites and Gadites in story B; Moses appears to be doing 
well with the apodosis in v. 23. Guilt before Yahweh should not logically entail inheritance of the Transjordanian land. Thus, the condition in story B, marked with the four-fold appearance of לפני יהוה and the notion that the land has not yet been given to the Gadites and Reubenites, reads: "If you go to battle to fight before Yahweh and every fighter among you crosses the Jordan before Yahweh, until he has dispossessed his enemies before him and the land has been subdued before Yahweh, and then you return, then this land shall be your holding before Yahweh." The condition in story A reads: "If you do this thing, you shall be clear before Yahweh and before Israel. If you do not do so, you will have sinned against Yahweh, and know that your sin will overtake you."13

Narratively, both of these conditions, one initiated by Moses and one initiated by the Reubenites and Gadites and confirmed by Moses, must be a reply to a request by the Reubenites and Gadites for the Transjordanian land. Two such requests are found in v. 5. The request for land in story B can be found in v. $5 \mathrm{a} \beta$ : "let this land be given to your servants as a holding." In vv. $22 \mathrm{~b}$ and $5 \mathrm{a} \beta$, the land is described as both הארץ הזאת and האחזה. Verse 22b is thus the direct response to v. $5 \mathrm{a}$ : the Reubenites and Gadites will be given this land as a holding, but only after they fulfill the condition Moses has set forth in vv. 2ob-22a $\alpha$. Preceding this request are vv. 2-3: the Gadites and Reubenites approach Moses, Eleazar and the leaders of the community (v. 2; see the similar list in 32:28; the addition of Joshua to v. 28 will be discussed below), enumerate the cities they desire (v. 3), and request the land (v. $5^{\mathrm{a} \beta}$ ).

The request in story A is found in v. $5^{a} \alpha$ and v. $5^{b}$ : "They said, 'if we find favor in your eyes, do not move us across the Jordan.' " This request dovetails nicely with the earlier observation that in story A the Israelites are currently living in the Transjordan. The Reubenites and Gadites are simply asking to be allowed to remain where they already are. Additionally, the verb מצא appears only twice in this chapter: in this request from v. 5 and in Moses' response (already identified as part of story A) in v. 23. It is interesting to note a literary play at work in these two verses. It was observed above that the use of the verb מצא to describe the action of sin was a bit odd. It may be that the author of story A is

all the negotiations. And yet, this turn of phrase at the end of v. 22 suggests that the rules or laws of Yahweh for the conquest of the land, set out fully in Numbers 2-4, are being amended to include this new promise.

13) ויאמר משה אליהם in v. 20 must have been present in both stories. In the process of combining the two stories, the compiler necessarily eliminated one of the two occurrences. See the similar examples of this phenomenon elsewhere: Exod 31:18; Num 11:11, 16; 13:26. For further discussion of this compilational practice see J. S. Baden, The Composition of the Pentateuch: Rewriting the Documentary Hypothesis (Anchor Yale Bible Reference Library; New Haven, 2012), 220-221. 
making a pointed statement in v. 23. The Reubenites and Gadites in v. 5 use the standard phrase "If we find favor" (אם מצאנו חן בעיניד) when making their request for the land of the Transjordan. Moses readily agrees in vv. 20a, 22a $\beta$, 23 , but does so with a reminder that just because they have found favor and their request has been granted does not mean that sin cannot then find them should they fail to fulfill their promise.

In story B, according to Numbers 31 the Israelites have conquered the Transjordanian land and subsequently left it (31:12). In story A, the Reubenites and Gadites are asking to remain in the land that the Israelites have been dwelling in for some time (Num 21:31). The two stories thus take place in two different locations. Story B takes place on the steppes of Moab, outside of the land in question, and story A takes place inside the territory in question.

The request in story A cannot begin in v. 5a ; ויאמרו requires an antecedent. This can be found in v. 1. The Reubenites and Gadites are introduced as having large numbers of cattle and desiring Jazer and Gilead because it was good cattle land. ${ }^{15}$ This theme of good cattle land is again mentioned in v. 4. The content of this verse, and especially the somewhat idiosyncratic description of Yahweh "striking" the land, accords best with story A. ${ }^{16}$ In Numbers 21:34, Yahweh tells Moses that he is giving King Og and all his people into Moses' hand. In Numbers 21:35, ויכו אתו they struck him (Og). Yahweh is not the subject of but can be understood as the agent behind the action. There is nothing like this in Numbers 31. The full request in story A thus begins in v. 1 and continues in vv. $4-5 \mathrm{a} \alpha, 5 \mathrm{~b}$.

The request for the Transjordanian land in story $\mathrm{B}$, however, has a second part. The Gadites and Reubenites request the Transjordanian land-the nine cities listed in v. 3 -in v. $5 \mathrm{a} \beta$, but they also request that they be allowed to build cities and sheepfolds (v. 16). As discussed earlier, the building of cities is at odds with story A and its dependence on the Transjordanian conquest

14) The phrase מצא חן appears in some form 21 times in the Pentateuch: Gen 6:8; 18:3; 30:27; $32: 6$; 33:8, 10, 15; 34:11; 47:25, 29; 50:4; Exod 33:12, 16, 17; 34:9; Num 11:11, 15; 32:5; Deut 24:1.

15) That the Reubenites and Gadites had large numbers of cattle seems a reasonable thing for story A to say, but an entirely unnecessary statement for story B. In story B, all of the Israelites have the same amount of cattle; the spoils of the Midianite war have just been apportioned equally among them (Num 31:36-41).

16) A number of commentators have focused primarily on the phrase עדת ישראל in this verse, some even to the exclusion of the verse's content when attributing it to a source or redactional layer. See Seebass, "Erwägungen," 36; Bacon, Triple Tradition, 240; Addis, Documents, 441; Gray, Numbers, 429; J. Scharbert, Numeri (Würzburg, 1992), 125-126. This phrase will be addressed in more detail below. 
narrative in Numbers 20-21; it is only in the Transjordanian conquest narrative in Numbers 31, on which story B is dependent, that the cities are entirely destroyed, thus necessitating that they be rebuilt. ${ }^{17}$ The Reubenites and Gadites, having just conquered this land with the rest of the Israelites in Numbers 31, see an opportunity. They want to live in the Transjordan rather than in Canaan and ask this of Moses, Eleazar, and the leaders of the community (vv. $2-3,5 \alpha \beta$ ). Moses reacts strongly to this request, responding in v. 6 by questioning their loyalty to the Israelites: "Are your brothers to go to war while you stay here?" In v. 16 the two tribes approach Moses alone and restate their request, offering a bit more detail. This request concludes in v. $17 \mathrm{~b}$ (as already noted, v. 17a with its mention of fighting לפני בני ישראל belongs to story A), saying that their children and flocks will stay in these towns and sheepfolds "because of the inhabitants of the land."

Moses is still not convinced and responds to the Reubenites and Gadites with a condition addressing both parts of their request: if they fight alongside the Israelites in Canaan, they can have the Transjordanian land as a holding (v. $\left.5 \mathrm{a} \beta / / \mathrm{vv} .20-22^{*}\right)$ and in the meantime they can rebuild the cities they have destroyed (vv. 16, 17b//v. 24a). Verse $24 \mathrm{~b}$ presents a problem. Moses ends his speech to the two tribes by telling them in v. 24 b to "do what you have promised." At this point in story B, the Reubenites and Gadites have promised nothing: they have merely stated their desires. It is Moses who has presented them with a way to fulfill those desires. It is not until v. 25 that they affirm their intention to fulfill Moses' condition and thus "promise" anything. Verse 24b cannot logically be part of story B. It does, however, accord perfectly with story A.

In v. 17a, 18-19, the Reubenites and Gadites make an unsolicited promise to Moses. It is these verses, "this thing," that Moses refers to when he says "do what you have promised" (v. 24b). In these verses, the two tribes offer to fight לפני בני ישראל until each of the Israelites is in possession of his portion. As shown above, the most apparent difference between the two accounts in Numbers 32 is that story A claims that the Transjordanian land is given to the Reubenites and Gadites before the land of Canaan is conquered (v. 33). It is thus significant that in v. 19 the two tribes say that they will not receive a portion in the Cisjordan because "we have received our share on the east side of

17) This evidence renders problematic the conclusion of Schmidt when he says that the request initiated in v. 5 , that the Reubenites and Gadites not be made to cross the Jordan, is subsequently emended by the two tribes in v. 16 in response to Moses' speech in v. 6. "Ansiedlung," 501. The tribes would like to remain where they have been living (as Schmidt rightly notes). However, that they would ask to build the cities they have already been living in, as they request in v. 16, is nonsensical. 
the Jordan." 18 This allows these verses to be positively identified as a part of story A. The speech initiated by the Reubenites and Gadites in v. 4 continues through v. $5^{\mathrm{a} \alpha}$ and v. $5^{\mathrm{b}}$ and into v. $17 \mathrm{a}, 18-19 .{ }^{19}$ The request and the promise are made in virtually the same breath and of their own accord. ${ }^{20}$

In story B the Gadites and Reubenites simply ask for the land. Moses responds to their request with a set of conditions in vv. $20-22^{*}$, and in vv. $25^{-27}$ the two אתכם ...לפני tribes promise to do as Moses has commanded and cross the Jordan יהוה to subdue the land of Canaan. Verses 25-27 are a natural unity and do not show any signs of having come from multiple hands. The Gadite and Reubenite response begun in v. 25, "your servants will do as my lord commands," followed by the nearly verbatim repetition of Moses' conditions from vv. 20-22* and concluded with another deferential statement "as my lord orders" in v. 27, indicates that they have not come up with this condition on their own; rather, Moses has placed this condition upon them. This accords nicely with what we know of story B. In story A, the condition comes from the Reubenites and Gadites themselves in vv. 17a, 18-19 in the form of a promise, and Moses agrees to "this thing," that is their simultaneous request and promise, in v. 20.

After the Reubenites and Gadites agree to Moses' condition in story B (vv. 25-27), Moses relays this agreement to Eleazar, Joshua and the leaders of

18) Here באה is a perfective form indicating a completed action and is possibly the perfectum confidentiae, designating a fact that is imminent and therefore in the imagination of the speaker, already accomplished. GKC §106n.

19) Schmidt has argued that v. 17a and vv.18-19 belong to different strata within this chapter. For him, the two tribes are responding to Moses' critique in v. 6 and clarifying their plan in vv. 16-17a. Schmidt understands vv.17b-19 to have been added by a late editor who is also responsible for the addition of vv. 28-32, thus creating the textual issue of when the Reubenites and Gadites will receive the Transjordanian land. However, as the present literary analysis has shown, 32:19 presumes that the land will have already been given to the two tribes prior to crossing the Jordan. At the very least v. 19 and v. 33 should belong to the same literary stratum since they share this same basic historical assumption. And yet, despite his recognition of the two different claims in Num 32 about the timing of the Reubenite and Gadite acquisition of the land, Schmidt assigns v. 33 to the earliest form of Numbers 32 and v. 19 to the latest redactional layer. See L. Schmidt, Das 4. Buch Mose Numeri: Kapitel 10,11-36,13 (Das Alte Testament Deutsch 7,2; Göttingen: Vandenhoeck \& Ruprecht, 2004), 197-200.

20) Some iteration of the phrase ויאמרו אל משה (v. 2) must have been present in both accounts. The compiler, when faced with combining these accounts, eliminated one of the two occurrences. There have been a number of arguments for the ויאמרו in v. 5 being an indication of another source. See Noth, Numbers, 232-237. However, the presence of ויאמרו in the midst of a speech is not abnormal in Biblical Hebrew. It occurs most frequently when the topic of the speech shifts, as it does in v. $5 \mathrm{a} \alpha$ from a description of the land to a request for that land (Cf. Gen 17:3, 9, 15). 
the tribes in vv. $28-30 .{ }^{21}$ The Reubenites and Gadites again declare their intention to fulfill this condition in vv. $31-32 .{ }^{22}$ The details of the condition in vv. 28-32 accord perfectly with the first iteration of the condition in story B in vv. 20-23 with one exception: v. 26. In this verse, the Gadites and Reubenites agree to help subdue the land of Canaan, "but our children, women, cattle, and all of our animals will remain here in the cities of Gilead." In v. 26 "women" and "all of our animals" have been included in the otherwise standard list of "children" and "livestock" found in vv.16, 17b, 24. The minor difference between vv. $16,17 \mathrm{~b}, 24$ and v. 26 becomes very important. In v. 16, the Gadites and Reubenites approach Moses to respond to his criticism and to clarify their initial proposal in v. $5^{a}$. $^{23}$ They want the land not simply as a temporary refuge from war, but as a permanent holding, akin to the tribal territories in the promised land. In vv. 16, 17 b, the Gadites and Reubenites' request mentions only children and flocks and can be understood as pertaining to the long-term future; they want their descendants and property to remain in this place (פה) permanently so that it will become their אחזה. ${ }^{24}$ Verse 26 has another agenda. Once Moses has conditionally agreed to allow the Gadites and Reubenites to take possession of the Transjordan at a future date, the two tribes state their immediate need. ${ }^{25}$ They wish to leave behind their wives, children, flocks, and animals,

21) Joshua is mentioned in this verse (and not in v. 2) precisely because he is the one who will have to apportion the land. In Num 14:29-30 we are told that none of the men who went up to spy out the land, save for Joshua and Caleb, will be allowed to enter the land of Canaan. Neither Moses nor Aaron will be allowed to enter the land with the people because of the incident at Meribah in Num 20:12. This duty to fulfill the distribution of the land then necessarily falls to Joshua and Eleazar, the only ones of that generation in this group enumerated in 32:28 who will be in a position to carry out this command. This reading challenges the view of Seebass who thinks that the "committee" is anchored in v. 28 and because this list does not match the one in v. 2 b, the latter must be a later addition. H. Seebass, "Erwägungen," 38.

22) Abravanel views this second affirmation as a problem. To him, the Gadites and Reubenites are responding to a speech that is made not to them but to Joshua, Eleazar and the chieftains of the tribes. In v. 2, the Gadites and Reubenites approach Moses, Eleazar and the chieftains of the community and make their request. In v. 20-24*, Moses alone responds to the Gadites and Reubenites with his conditions. The two tribes make a private affirmation to Moses in vv. 25-27. In vv. 28-30, Moses relays the agreed-upon conditions to Eleazar, Joshua and the tribal leaders. The Gadites and Reubenites then publicly affirm their commitment to this agreement in vv. 31-32.

23) A similar suggestion was made by Abravanel: the tribes approached Moses because they thought he did not understand them. They then explained it privately so as not to embarrass him. Abravanel, on v. 16. See also Schmidt, "Ansiedlung," 499.

24) Joel S. Baden, personal communication.

25) Contra Simpson who views v. 26 as a "pedantic enumeration" and attributes it to Rp (Early Traditions, 274). 
while they help subdue Canaan. ${ }^{26}$ The use of שם in v. 26 as opposed to פה v. 6, 16 is literarily notable. The Gadites and Reubenites are rhetorically distancing themselves from the land in question at this crucial point in the narrative. That "wives" and "all of their animals" are included in v. 26 only strengthens this argument. Verses 16 and $17 \mathrm{~b}$ are generalized statements whereas v. 26 specifically details the property they intend to leave behind. ${ }^{27}$

Verses 34-38, in which the Gadites and Reubenites rebuild and rename a number of cities, are naturally the fulfillment of the request of the two tribes in vv. 16, 17b, and Moses' assent to that request in v. 24a, all a part of story B. Immediately after finalizing and formalizing the conditions of their agreement in vv. 25-32, the Gadites and Reubenites rebuild the cities. The list of cities in vv. 34-38 is frequently, and rightly, connected with the list of cities in v. 3. Some scholars have taken vv. $34-38$ to be a secondary addition to the text, deliberately expanding on v. $3 .{ }^{28}$ This need not be the case. Verses $34-38$ make perfect sense in the narrative of story B: Moses tells the Gadites and Reubenites to rebuild the cities, and they do. Most arguments for the secondary nature of these verses focus on the variations in the names. That the names do not match, however, is plausibly explained within the text itself: "they changed the names of the cities that they rebuilt" (v. $38 b) .{ }^{29}$

26) The presence of the material in v. 26 in Deuteronomy's retelling of this story in 3:12-20 raises some questions about the relationship between the two texts that cannot be fully addressed in this article. The issue of the relationship between Deuteronomy and its parallel narratives in Exodus-Numbers is a fraught topic in biblical scholarship and there are a number of possibilities for understanding Deuteronomy's seeming knowledge of both the A and B strands in Numbers 32 . Briefly: 1) the passage in Deut 3:12-20 is post-compilational, or 2) Deut 3:12-20 has been edited in light of the combined narrative of Num 32 . The scenario that seems impossible, given my above analysis of Numbers 32 , is that 32:26 is an addition to Numbers in light of Deut 3:12-20. (See Achenbach, Vollendung, 374-376 for this latter argument.)

27) In 31:9, the Israelites take captive the Midianite women and children and their flocks and their herds (את נשי מדין ואת טפם ואת כל בהמתם ואת כל מקנהם). Clearly the women and children in 32:26 are not the Midianite women and children, but rather the Israelite women and children. Still, the lexical similarities are striking. It is possible that Seidel's law is in effect in these two verses. In 32:26 the order is children, women // flocks, livestock. In 31:9 it is women, children // livestock, flocks.

28) For examples of this, see Simpson, Early Traditions, 275-276 or Noth, Numbers, 232-237. Bacon argues that the list of cities in vv. $34-38$ is near enough to v. 3 that we know they intend to refer to the same geographical areas, but he claims there is enough difference between the two lists to say that they cannot be written by the same hand. Bacon, Triple Tradition, 235. Van Seters understands vv. 34-38 to be part of J's distribution of the land and v. 3 to be the later gloss. Van Seters, Life 438 .

29) Schmidt argues that the notice in v. 38, מוסבת שם, is likely a secondary addition. "Ansiedlung," 505. While this is possible, it does not affect the literary analysis in any way. This phrase 
Apart from vv. 7-15, only vv. 39-42 remain. These verses, detailing the conquest of Gilead by the Machirites, cannot belong to the same hand as vv. $34-38 .^{30}$ In story B Gilead has already been conquered, as is clear from the reference to Gilead in v. 26. That the cities listed in v. 3 are part of the region of Gilead may well have been common knowledge. In story A, however, the only land that has been conquered according to Numbers 21 is that of "Jazer" (21:32), which is described as belonging to Sihon, King of the Amorites (21:31). This is precisely the land given to the Reubenites and Gadites in 32:33. Gilead is mentioned only in v. 39 when it is conquered for the first time in story A by the descendants of Machir and in v. 40 when Moses gives that land to them. ${ }^{31}$ This distribution of land prior to the conquest of Canaan fits quite well with the pattern found in story A.

A narrative problem with attributing vv. 39-42 to story A arises with the presence of the phrase "and the land of Gilead" in v. 1. ${ }^{32}$ In v. 4, the Reubenites and Gadites tell Moses that the land conquered by Yahweh is good cattle land. This must be the same land referred to in v. 1: Jazer and Gilead. For this reason most scholars claim secondary status for vv. 39-42: they understand that the land has already been conquered and thus cannot be conquered a second time. ${ }^{33}$ Yet Numbers 20-21 never narrates the conquest of Gilead, and, apart from v. 1, story A in Numbers 32 does not mention Gilead until v. 39 when the Machirites are said to conquer it. Story B, on the other hand, deals only with

does not contradict, but rather simply anticipates v. 38 b. Explained another way, v. $38 \mathrm{~b}$ expands upon מוסבת שם.

30) A number of scholars view these verses as the historical core of the chapter and a remnant of the original tradition of the eastern settlement: Noth, History, 72-73; S. Mowinckel, Erwägungen zur Pentateuch Quellenfrage (Oslo, 1964), 103-104; J. de Vaulx, Les Nombres (Paris, 1972), 363-64.

31) Numbers 21:32 does speak of the Israelites dispossessing האמרי אשר שם, the Amorites who were living there, but there are no grounds to claim that this notice of dispossession refers to anything more than the individual cities of Sihon named in Numbers 21:26-32. It is only with the territory of Og that we are told the Israelites ויכו אתו ואת בניו ואת כל עמו עד בלתי השאיר לו שריד, "they conquered him and his sons and all of his people until no remaining survivor was left for him (v. 35). No such notice is given for the territory of Sihon or the Amorites, and it is plausible that they were not completely destroyed in Numbers 21 as the people of Og were.

32) Schmidt rightly recognizes this phrase as causing a narrative difficulty, though he does not arrive at the correct conclusion, arguing instead that המקום in v. 1 serves to summarize the aforementioned regions of Jazer and Gilead and that all of v. 1 is therefore original to the narrative. "Ansiedlung," 497-498; Numeri, 198. Seebass also recognizes this problem in his commentary, but simply says that if the geographical issue is set aside, this verse belongs to the base layer. He does not explain the origin of the problem or propose a solution. H. Seebass, Numeri (Biblische Kommentar Altes Testament 4:3; Neukirchen Vluyn: Neukirchen Verlag, 2007), 329.

33) Bacon, Triple Tradition, 235. Noting the resemblance of these verses to Judges 1, Gray argues that it originally belonged to the account of the conquest after Moses' death (Numbers, 438). Cf. Simpson, Early Traditions, 276; Carpenter and Harford Battersby, Hexateuch, 241. 
the "cities of Gilead." ${ }^{4}$ The compiler, when combining these stories, would have had no choice but to add ואת ארץ גלעד to v. 1 in order for the composite story to make sense. Without this phrase, story A progresses quite logically: the Reubenites and Gadites request the land in the Transjordan and promise to help the Israelites gain possession of Canaan. Moses agrees and gives them the land, thus effectively enlarging the borders of the promised land (v. 33). Seeing this, the descendants of Machir go off and conquer the cities and towns of Gilead. Moses then gives them the land, enlarging the promised land even further (vv. 39-40). Verses 41-42 can be read as a continuation of vv. 39-40 and need not be separated on narrative grounds. ${ }^{35}$

Given this two-stage apportionment of the Transjordan in story A-the lands of Jazer are given to the Reubenites and Gadites (v. 33) and the lands of Gilead are given to the descendants of Machir (v. 40) - verse 33 presents another problem. There Moses gives the land to "the Gadites, Reubenites and the half tribe of Manasseh son of Joseph." At this point in story A, however, Moses cannot give the land to the half tribe of Manasseh because they have not yet conquered Gilead. Most scholars agree that the inclusion of the half tribe of Manasseh in this verse is secondary. ${ }^{36}$ This insertion is quite likely the result of

34) Num 32:3, 26, 29 and presumably 34-38.

35) That these verses might be a later insertion is certainly possible. Story A follows a pattern of conquest - request - apportionment for both the Reubenites and Gadites and the Manassites in vv. 39-40. This pattern is not followed in vv. 41-42.

36) The issue of the seemingly sudden insertion of the half-tribe of Manasseh is one that has been discussed at length. The majority of scholars understand this phrase to be a late redactional insertion. Wellhausen, Composition, 349 gives this phrase to the latest legal layer; Noth, Numbers, 237238, and Lohfink, Theology, 216-218 assign this phrase to a later redactional layer in the Deuteronomistic-priestly style; Bacon, Triple Tradition, 235 attributes it to Rd; Loewenstamm, "Settlement," 130 gives it to his latest layer; Seebass, "Erwägungen," 38 sees it as an addition that provides a link to Deut 3:12-20; Schmidt, "Ansiedlung," 506 also takes the mention of the half tribe of Manasseh as a late secondary insertion; Baden, Redaction, 144 attributes this phrase to the compiler. Kuenen, Hexateuch, 101 suggests that an original story may have dealt with Reuben and Gad on the one hand and the half-tribe of Manasseh on the other. The medievals understand the addition of the half-tribe of Manasseh in a couple of different ways. Commenting on v. 33, Nachmanides suggests that they came forward only after the request of the Reubenites and Gadites was accepted. Ibn Ezra suggests that the half tribe of Manasseh was unimportant enough (being only half a tribe) that the text chose not to mention them until now. It is most plausible that the phrase לבני גד ולבני ראובן ולחצי שבט מנשה בן יוסף is a later insertion, from the same stratum as vv. 7-15, which will be discussed in detail below. Contra Schmidt, I think these nine words are the extent of the insertion and that mention of the kingdoms of Sihon and Og, dependent on Numbers 21, are original to story A in Numbers 32 . Most scholars argue, with Schmidt, that Num 21:33-35, narrating the conquest of the territory of $\mathrm{Og}$, is a secondary addition. If this is the case, then the phrase ואת ממלכת עג מלך הבשן Num 32:33 must also be secondary. At this time, 
knowledge of the parallel accounts in Deuteronomy and Joshua. Those texts conflate the Numbers stories about the Transjordan and do not distinguish between the multiple stages of conquest in story A (stage one: Numbers 20-21, stage two: Numbers 32:39-42). The addition of this clause is best understood as a post-compilational attempt to harmonize the Numbers account with later versions of the story. ${ }^{37}$

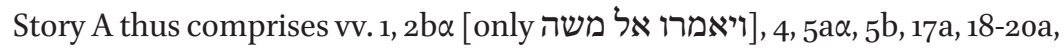
$22 \mathrm{a} \beta, 23,24 \beta, 33 \mathrm{a} \alpha, 33 \mathrm{~b}, 39-42$. The Reubenites and Gadites, being rich with cattle, recognize the Transjordan as good cattle land. The two tribes approach Moses with a proposition: if they are allowed to keep the Transjordan as their portion, they will forgo their portion in the Cisjordan but still promise to help the rest of the Israelites attain their portions. Moses agrees and tells them that if they do this thing, they shall be innocent before Yahweh and before Israel. If they do not do this thing they will have sinned against Yahweh and their sin will find them. Moses concludes his speech by telling them to do as they have promised. He then gives them the land they have requested (v. 33). Seeing this, the Machirites go out and conquer Gilead and the surrounding towns and Moses then gives them the land (vv. 39-42).

Story B comprises vv. 2-3, 5a $\beta, 6,16,17 b, 20 a \alpha$ [only ויאמר אליהם משה], 2ob-22a $\alpha, 22$ b, 24a, 25-32, 34-38. In this story, the Gadites and Reubenites approach Moses, Eleazar, and the leaders of the community to request that nine cities be given to them as an אחזה. Moses responds by questioning their loyalty. The two tribes elaborate on their request by asking to build sheepfolds and cities for their flocks and children to permanently dwell in (at a future date). Moses agrees, but with a condition: the Gadites and Reubenites must cross the Jordan with the Israelites and fight לפני יהוה to help subdue Canaan. Once this is complete, then they can have the land they requested as an אחזה. He tells them that they may build their cities and sheepfolds. The two tribes agree to these conditions. Moses relays the conditions to Joshua, Eleazar and the leaders of the tribes, instructing them to carry out the apportionment of the Transjordan to the Gadites and Reubenites after the conquest of Canaan.

\footnotetext{
I find no compelling reason for Num 21:33-35 to be a secondary addition. Thus v. 32:33a $\beta$ need not be included in the later insertion.

37) Support for the later association of Reubenites and Gadites with the half tribe of Manasseh is found in manuscripts from Qumran as well as in the Samaritan Pentateuch. In 4QNum, Col XXVII, fragments 6o-64, every time the Reubenites and Gadites are mentioned, beginning in v. 1, the half tribe of Manasseh has been added. The same situation obtains in the Samaritan version. E. Ulrich, F. M. Cross, J. T. Milik, and P. W. Skehan, eds., The Biblical Qumran Scrolls: Transcriptions and Textual Variants (Supplements to Vetus Testamentum) Leiden; Boston, 2010), 164-165.
} 
The two tribes publicly affirm their willingness to fulfill these conditions and then rebuild and rename the cities destroyed in Numbers 31.

\section{Full Text of Each Story:}

\section{Story A:}

Num. 32:1 The Reubenites and the Gadites owned cattle in very great numbers. Noting that the land of Jazer was a region suitable for cattle, 2 They said to Moses, 4 "The land that Yahweh has conquered for the IIsraelites $\}$ is cattle country, and your servants have cattle." 5 They continued, "If we find favor in your eyes, do not move us across the Jordan. 17 We will hasten to fight at the head of the Israelites until we have established them in their home. 18 We will not return to our homes until every one of the Israelites is in possesion of his portion. 19 But we will not have a share with them in the territory beyond the Jordan, for we have received our share on the east side of the Jordan." 20 Moses said to them, "If you do this, 22 you shall be clear before Yahweh and before Israel. 23 But if you do not do so, you will have sinned against Yahweh; and know that your sin will overtake you. 24 Do what you have promised." 33 So Moses assigned to them the kingdom of Sihon king of the Amorites and the kingdom of King Og of Bashan, the land with its various cities and the territories of their surrounding towns. 39 The descendants of Machir son of Manasseh went to Gilead and captured it, dispossessing the Amorites who were there; 40 so Moses gave Gilead to Machir son of Manasseh, and he settled there. 41 Jair son of Manasseh went and captured their villages, which he renamed Havvoth-jair. 42 And Nobah went and captured Kenath and its dependencies, renaming it Nobah after himself.

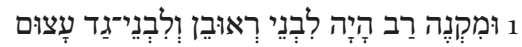

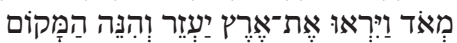

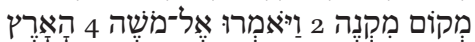

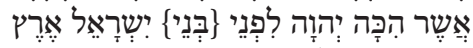

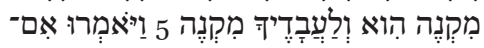

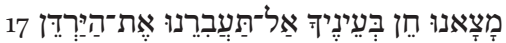

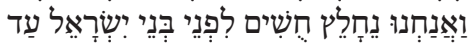

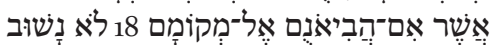

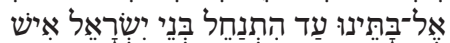

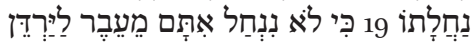

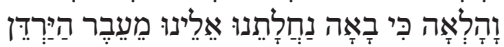

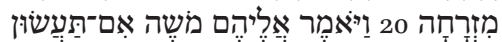

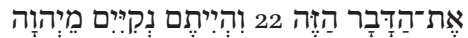

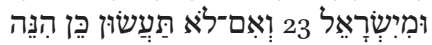

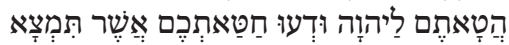

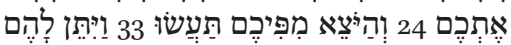

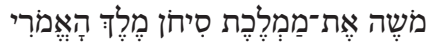

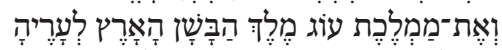

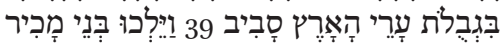

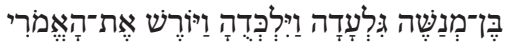

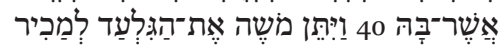

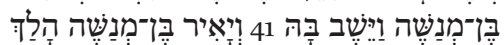

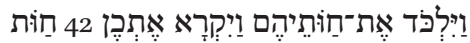

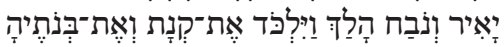

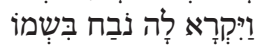


Story B:

Num 32:2 The Gadites and the Reubenites came to Moses, Eleazar the priest, and the chieftains of the community, and said, 3 "Ataroth, Dibon, Jazer, Nimrah, Heshbon, Elealeh, Sebam, Nebo, and Beon, 5 let this land be given to your servants as a holding." $\underline{6}$ Moses replied to the Gadites and the Reubenites, "Are your brothers to go to war while you stay here?" 16 Then they stepped up to him and said, "We will build here sheepfolds for our flocks and towns for our children. 17 And our children stay in the fortified towns because of the inhabitants of the land." 20 Moses said to them, "If you go to battle as shock-troops, at the instance of Yahweh, $\underline{21}$ and every shock-fighter among you crosses the Jordan, at the instance of Yahweh, until He has dispossessed His enemies before Him, $\underline{22}$ and the land has been subdued, at the instance of Yahweh, and then you return, this land shall be your holding under Yahweh. 24 Build towns for your children and sheepfolds for your flocks." 25 The Gadites and the Reubenites answered Moses, "Your servants will do as my lord commands. 266 Our children, our wives, our flocks, and all our other livestock will stay behind in the towns of Gilead; 27 while your servants, all those recruited for war, cross over, at the instance of Yahweh, to engage in battle-as my lord orders." $\underline{28}$ Then Moses gave instructions concerning them to Eleazar the priest, Joshua son of Nun, and the family heads of the Israelite tribes. 29 Moses said to them, "If every shock-fighter among the Gadites and the Reubenites crosses the Jordan with you to do battle, at the instance of Yahweh, and the land is

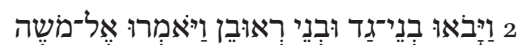

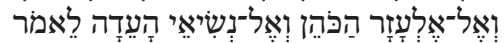

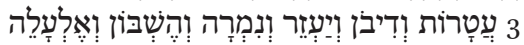

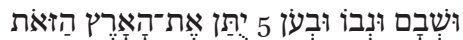

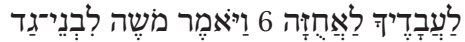

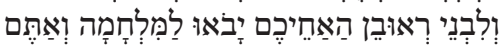

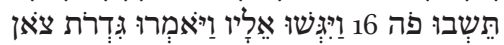

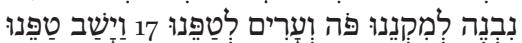

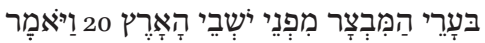

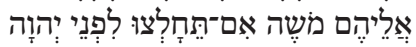

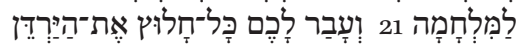

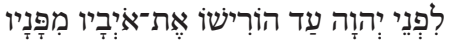

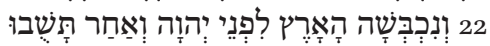

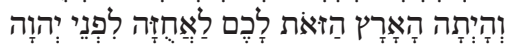

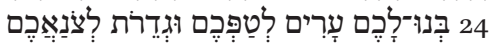

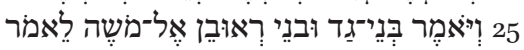

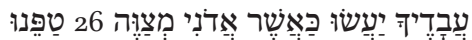

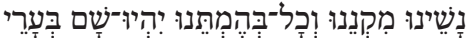

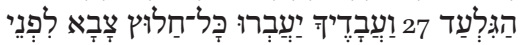

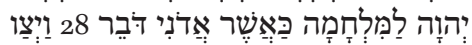

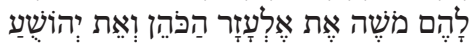

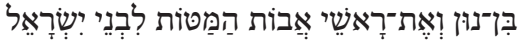

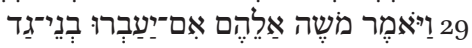

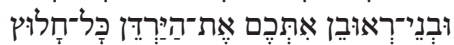

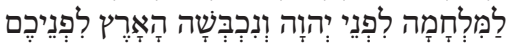

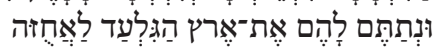

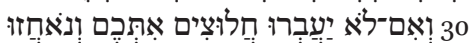

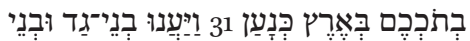

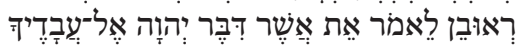

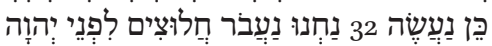

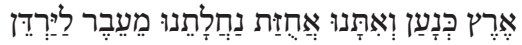

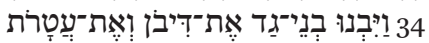

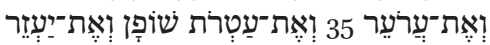

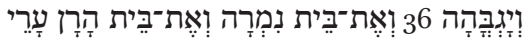

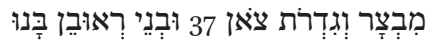

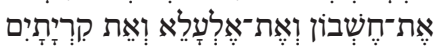

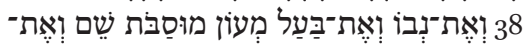

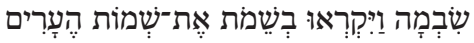

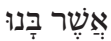


subdued before you, you shall give them the land of Gilead as a holding. 30 But if they do not cross over with you as shocktroops, they shall receive holdings among you in the land of Canaan." 31 The Gadites and the Reubenites said in reply,

"Whatever Yahweh has spoken concerning your servants, that we will do. $32 \mathrm{We}$ ourselves will cross over as shock-troops, at the instance of Yahweh, into the land of Canaan; and we shall keep our hereditary holding across the Jordan." 34 The Gadites rebuilt Dibon, Ataroth, Aroer, 35 Atroth-shophan, Jazer, Jogbehah, 36 Beth-nimrah, and Beth-haran as fortified towns or as enclosures for flocks. 37 The Reubenites rebuilt Heshbon, Elealeh, Kiriathaim, 38 Nebo, Baal-meon-some names being changed-and Sibmah; they gave [their own] names to towns that they rebuilt. ${ }^{38}$

\section{Connections within the Pentateuch}

I have shown that there are two distinct coherent, continuous, and complete narratives in Numbers 32 which have been combined into a single account of the apportionment of the Transjordan. At a number of points in the literary analysis above, it has been clear that these two narratives presuppose material found elsewhere in the Pentateuch. These connections provide a deeper insight into the narratives in Numbers 32 , and indeed the two stories in this chapter are fully comprehensible only when read in the context of their respective narrative strands in the Pentateuch.

Turning first to the longer of the two stories, story B contains numerous connections with texts outside of Numbers 32 . I have already argued that the image of the Israelite battle formation in this story accords perfectly with, and in fact

38) When the two stories are laid out in this manner, it becomes apparent that each of the two individual accounts preserves the exact order of the verses in the canonical account of Numbers 32 . While a full discussion of the method of compilation is beyond the scope of this analysis, suffice it to say that the chronological sequence is preserved in each individual story and is the sole criterion used in combining them into a single, canonical account. 
depends upon, the fuller description presented in Numbers 2-4. It has also been shown that because this story assumed the cities of the Transjordan to have been completely destroyed, it is a logical continuation of the account of the war with the Midianites in Numbers 31. Both Numbers 2-4 and Numbers 31 are widely recognized as priestly in origin. Story B also makes a seemingly offhanded comment in v. 17b, wherein the Gadites and Reubenites ask Moses to permit them to build cities and sheepfolds in the Transjordan "because of the inhabitants of the land." The context for this comment is found in the priestly spies story in Numbers 13-14. In 13:32, the men who scouted out the land tell Moses that it is uninhabitable because it devours its inhabitants and its people are of a great size. Numbers 14:3 continues this complaint, saying that the wives and children of the Israelites will be taken as plunder, presumably by these very large people. The concern about the very large people is present in the non-priestly spies story as well (Num 13:33), but the concern for wives and children is unique to the priestly spies story and is picked up on in these verses just prior to the Israelites' second entry into Canaan.

Beyond these narrative connections, there are certain words and phrases unique to each story. In story B, which can now be identified as priestly ${ }^{39}$ with relative certainty based on its connections with and dependence upon at least three other priestly texts, there are a number of lexical connections to other priestly texts. With the exception of Deuteronomy 10:6, Eleazar appears only in the priestly materials in the Pentateuch, ${ }^{40}$ and the word עדה is also largely recognized as uniquely priestly. ${ }^{41}$ The association of עדה with the priestly source is so strong, in fact, that many scholars have assigned Numbers $32: 4$ to $\mathrm{P}$ on the basis of this word alone. ${ }^{42}$ Yet it is important to recognize that $32: 4$ is unique in its use of the phrase עדת ישראל. In most cases (Exod 12:3, 6, 47; Lev 4:13) the full priestly phrase is כל (קהל) עדת ישראל Twדת Twice it occurs as מערת (2xis

\footnotetext{
39) While there is a small minority of scholars who do not believe that there is an independent $P$ source or stratum within the Pentateuch, the majority of scholars are in agreement as to its existence, though certainly not its scope. For a more full version of this argument, see R. Kratz, "The Pentateuch in Current Research: Consensus and Debate," in The Pentateuch: International Perspectives on Current Research (ed. T. Dozeman, K. Schmid and B. J. Schwartz; Tübingen: Mohr Siebeck, 2011), 31-61.

40) See Exod 6:23, 25; 28:1; Lev 10:6, 12, 16; Num 3:2, 4, 32; 4:16; 17:2, 4; 19:3, 4; 20:25, 26, 28; 25:7, 11; $26: 1,3,60,63 ; 27: 2,19,21,22 ; 31: 6,12,13,21,26,29,31,41,51,54 ; 32: 2,28 ; 34: 17$.

41) See, for example, A. Hurvitz, "Linguistic observations on the priestly term 'edah and the language of P" Immanuel 1 (1978): 21-23; J. Milgrom, "Priestly Terminology and the Political and Social Structure of Pre-Monarchic Israel" Jewish Quarterly Review 69 (1978): 65-81.

42) See note 16. These scholars assign the verse either in whole or in part to $P$ or posit some level of priestly supplementation or redaction within the verse on the basis of the word עדה.
} 
ישראל (Exod 12:19; Num 16:9). ${ }^{43}$ Only here is it used on its own. The Septuagint

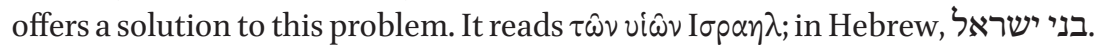
Given the narrative connections to other non-priestly texts and the unique nature of עדת ישראל in this verse, there are sufficient grounds to read with the LXX. ${ }^{44}$ Reading with the LXX eliminates any reason to attribute this verse to the priestly story and maintains עדה as a uniquely priestly term. ${ }^{45}$ Within Numbers 32 , there are a number of terms found only in the P story. They are אלעזר, נשיאי העדה לפני יהוה ,יהושע, ראשי אבות המטות ,בארץ כנען,

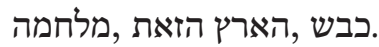

Considering the P story in Numbers 32 on its own, a broader theological stance emerges that is consistent with other priestly texts in the Pentateuch. In this story, the punishment for failing to fulfill Moses' condition is that the two tribes will simply inherit land alongside their fellow Israelites in Canaan (v. 30). Yet, the priestly account goes to great lengths to ensure that the order prescribed for the conquest earlier in the priestly document is carried out. Deviation from a prescribed order is allowed only if and when the goal has been realized: in this case, when Canaan is subdued. ${ }^{46}$ Thus, when the Gadites and Reubenites say in v. 31, "whatever Yahweh commanded to your servants, thus we shall do," they are acceding not only to the terms of their agreement with Moses, but also to the terms of Yahweh as regards conquering the land of Canaan, established in Numbers 2-4.

Story A is the shorter of the two stories, but still contains many connections to narratives outside Numbers 32 . First and foremost, only story A speaks of the lands of Sihon and Og. Outside of Numbers 32, these two kings are mentioned in the Pentateuch only in Numbers 21 and in Deuteronomy. ${ }^{47}$ Numbers 32 presupposes that the lands of Sihon and Og have been conquered, an event narrated in Numbers 21:21-35. The dependence of Numbers 32 on Numbers 21:21-35

\footnotetext{
43) Both of these occurrences of מעדת ישראל happen in $\mathrm{H}$ texts. While the addition of the preposition does not significantly change the meaning of this phrase, it has been argued that $\mathrm{H}$ often uses priestly language in a less precise manner than P proper, which may well be what is happening in these two cases. For a fuller presentation of this argument, see J. Milgrom, Leviticus 17-22: A New Translation with Introduction and Commentary (Anchor Yale Bible 3 A; New Haven, 2008), 1327-1330.

44) Rudolph also suggests this emendation. See W. Rudolph, Der Elohist von Exodus bis Josua (Berlin, 1938), 132. Seebass uses this phrase as the basis of his claim that there is the beginning of a late priestly redaction in vv. 2b-4a $\alpha$. Numeri, 330 .

45) It is possible that a scribe was influenced by נשיאי העדה in v. 2 while composing v. 4.

46) Lowenstamm makes a similar observation though applies it to the entirety of vv. 1-38. "Settlement," 110 .

47) Num 32:33; Deut 1:4; 2:24, 26, 30-32; 3:2, 6; 4:46; 29:6; 31:4.
} 
is made even clearer by the close literary relationship between the two chapters. In 21:32 the conquest of Jazer is narrated: וילכדו בנתיה וירשו את האמרי וילכד וילכדה ויורש את־האמרי :

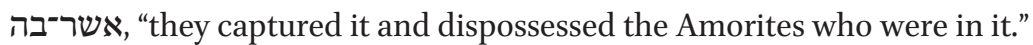

Secondly, the conception of battle in this story clearly does not accord with priestly texts. There are two conceptions of war in the non-priestly, non-Deuteronomic accounts of war in the Pentateuch. In one, Yahweh leads the Israelites into battle, and in the other Yahweh is noticeably absent or behind the scenes. ${ }^{48}$ In the non-priestly account in Numbers 32 , Yahweh is, for the most part, absent. Instead, the two tribes promise that they, not Yahweh, will be the ones leading the Israelites across the Jordan. Another connection is found in vv. 39-42 with the presence of the descendants of Machir son of Manasseh. This half-tribe first appears in Genesis 50:23 when they are said to have been born upon Joseph's knees. They do not appear again until Num 27:149 and Num 32:39-40. Their presence in Genesis 50 serves to legitimate them as a tribe of Israel and thus lays the foundation for their independent conquest and inheritance in the Transjordan in Numbers 32 . Every text I have connected to the non-priestly account in Numbers 32 belongs to the larger independent E source in the Pentateuch. ${ }^{50}$ Finally, after the time of Joseph, only $\mathrm{P}$ and E narrate events related to specific tribes; J speaks of Israel solely as a single entity. ${ }^{51}$ The non-priestly story in Numbers 32 is thus most logically part of the E narrative.

As with the P story, there are words and phrases unique to the E story in Numbers 32. They are:מכיר, מצום, מעבר הירדן, מנשה.

A final literary observation can be made about the naming of the tribes in each story. Only once, right at the beginning in v. 1, are the two tribes called the

48) In the non-priestly conception of war, Yahweh either should be leading the Israelites into battle (see Num 10:33 (J), Deut 31:8 (D) and Josh 3:3) or seems not to be actively present in the narrative until after the battle (see Num 21:21-35 (E)).

49) Numbers 27:1-11 is widely recognized as belonging to H. See especially S. Chavel, "Law and Narrative in Four Oracular Novellae in the Pentateuch: Lev 24:10-23; Num 9:1-14; 15:32-36; 27:1-11" (Hebrew University, 2006). [Hebrew]. That $\mathrm{H}$ is aware of and at times makes literary re-use of certain non-priestly texts has been convincingly argued by Stackert. See J. Stackert, Rewriting the Torah: Literary Revision in Deuteronomy \& the Holiness Legislation (Forschungen zum Alten Testament; Tübingen, 2007).

50) See Baden, Composition, 103-128; J. S. Baden, "The Narratives of Numbers 20-21," forthcoming; B. J. Schwartz, "Reexamining the Fate of the Canaanites in the Torah Traditions," in Sefer Moshe: The Moshe Weinfeld Jubilee Volume: Studies in the Bible and the Ancient Near East, Qumran, and Post-Biblical Judaism (ed. C. Cohen, A. Hurvitz, and S.M. Paul; Winona Lake, 2004), 151-170.

51) J. S. Baden, "From Joseph to Moses: The Narratives of Exodus 1-2" VT 62 (2012), 153. 
"Reubenites and Gadites." In vv. 2, 6, 25, 29, 31, all from P, the two tribes are called the "Gadites and Reubenites." Like v. 1, v. 33 belongs to E, though as discussed above, the phrase containing "to the Gadites, Reubenites, and half tribe of Manasseh son of Joseph" is a secondary insertion. As such, it is likely that whoever inserted this clause was influenced by the dominant phrase "Gadites and Reubenites." It should be noted that when the two tribes rebuild the cities in vv. 34-38, the actions of the Gadites are narrated first followed by the Reubenites.

\section{Numbers 32:7-15}

In the preceding analysis of Numbers 32 , when elements clearly belonging to different sources were separated, complete sentences and coherent and consistent narratives emerged. That is not the case with vv. 7-15, the reminiscence of the spies story in Numbers $13-14$. When we separate elements that refer to the different $\mathrm{J}$ and $\mathrm{P}$ accounts of the spies story in these verses, we are left with isolated phrases and incomplete sentences. In v. 9, the naming of the place to which the Israelites go is distinctly J: wadi Eshcol (Num 13:24). The idea that Caleb and Joshua are spared belongs to P, but the idea that they were spared because of their loyalty (מלאו אחרי יהוה) is J (Num 14:24). The reference to Kadesh Barnea in v. 8 appears in Deuteronomy 1:29, and the reference to Joshua as a Kenizzite in v. 12 is found elsewhere only in Joshua 14:6, 14. The idea that the entire generation is to perish in the wilderness belongs to J (Num 14:22-23). In $\mathrm{P}$, it is just the men of fighting age who have spurned Yahweh who are to die (Num 14:29-30). In this last case both ideas are present in Numbers 32:7-15, the former in v. 13 and the latter in v. 11. Numbers 32:7-15 thus contains a haphazard mixture of elements belonging to J, P, D, and even Joshua. While causing a problem for source-critical analysis, this mixture of elements also suggests the solution.

This conflation of phrases and ideas from J, P, D, and Joshua indicates an author cognizant only of the combined narrative in Numbers $13^{-14} 4^{52}$ and aware

52) See Baden, Redaction, 143 for this argument. Baden makes this argument based on the assumption that the compiler inserted phrases into Numbers $3^{2}$ to reconcile this account with the now-combined spies story in Numbers 13-14. While innovative, this is not something that the compiler is seen to do elsewhere. The details are so minor that they do not significantly change the meaning of the story. That the spies began at Kadesh-Barnea or went to the wadi Eshcol is not enough of a contradiction or narrative problem to warrant the intervention of the compiler per Baden's own conception of how the compiler works. The compiler "is not a historian-he is not concerned with giving the one accurate account of Israel's early history. And above all he is not an interpreter; he does not create new theological concepts." Baden, Composition, 226-227. 
of details present in Deuteronomy and Joshua. The author of these verses combines the details readily and almost thoughtlessly; he does not know the individual stories, but rather the canonical account. The most logical explanation for these verses is that they were added after the compilation of the Pentateuch and were influenced by deuteronomistic rhetorical style, though not by its ideology. ${ }^{53}$

Indeed, Numbers 32:7-15 is widely recognized as a secondary insertion for these exact reasons. ${ }^{54}$ These verses build upon Moses' question in v. 6, but have no narrative connection with any other part of Numbers 32 . The independent $\mathrm{P}$ and $\mathrm{E}$ accounts likewise make no reference to these verses. ${ }^{55}$ Precisely when these verses were added remains under debate, but that they are a postcompilational insertion remains the most logical suggestion. ${ }^{56}$ These verses could not have been added to an independent E account because the content of vv. 7-15 directly contradicts the narrative claims of the E wilderness account. ${ }^{57}$ If anything, the ideology looks primarily priestly in nature.Yet these verses can-

If an "accurate" rendering of the spies story is the impetus for the addition of Kadesh Barnea or the wadi Eshcol, it should not be of major significance to the compiler. And if theological interpretation is not of import, then the addition of Caleb's loyalty to the priestly story seems rather unnecessary.

53) Similar arguments have been made to demonstrate the post-compilational character of passages such as Exodus 34. The way source material in Numbers 32:7-15 is treated is strikingly similar to that in Exodus 34. See S. Bar-On, "The Festival Calendars in Exodus xxiii 14-19 and xxxiv 18-26” VT 48 (1998): 161-95; E. Blum, “Das sog. 'Privilegrecht' in Exodus 34,11-26: ein Fixpunkt der Komposition des Exodusbuches?" in Studies in the Book of Exodus (ed. M. Vervenne; Louvain, 1996), 347-366.

54) Among others, see Kuenen, Hexateuch, 101; Seebass, "Erwägungen," 37; Achenbach, Vollendung, 381-382; Simpson, Early Traditions, 272; Loewenstamm, "Settlement," 129; Schmidt, "Ansiedlung," 500; Licht, Bamidbar, 168-169.

55) They "do not involve any change in the main course of the narrative." Loewenstamm, "Settlement," 111.

56) See Baden, Redaction, 145 n. 124 for an attribution of these verses to P, and also Carr's apt critique of Baden's reading. D. Carr, "Scribal Processes of Coordination/Harmonization and the Formation of the First Hexateuch(s)" in The Pentateuch: International Perspectives on Current Research (ed. T. Dozeman, K. Schmid and B. J. Schwartz; Tübingen: Mohr Siebeck, 2011), 74 n. 29. This understanding of vv. 7-15 as a post-compilational addition bears some similarity to nondocumentary approaches to the Pentateuch. However, this type of post-compilational addition should be perfectly acceptable within the documentary model as long as it does not affect either of the two independent narratives.

57) There is no equivalent in $\mathrm{E}$ to the spies story and no condemnation of the Israelites to wander in the wilderness for forty years. The generation that left Egypt is the same generation to enter the land. Baden, "Joseph to Moses," 149. 
not be attributed to a secondary strata of P. ${ }^{58}$ The Holiness stratum is concerned with revising priestly texts only under two conditions: revision of priestly legislation or revision of priestly narratives that fundamentally contradict theological claims made by $\mathrm{H}^{59}$ Other non-H secondary strata of $\mathrm{P}$ deal with strictly legal matters. ${ }^{60}$ Verses 7-15 do not fit either of these descriptions.

The question of why someone would add vv. 7-15 to Numbers 32 is a different matter entirely. In form and content, these verses look like nothing else in the Pentateuch. ${ }^{61}$ A number of scholars have noted the distinctly theological and homiletical nature of this section. ${ }^{62}$ In fact, these verses look positively midrashic. In v. 6, Moses poses a simple question to the Reubenites and Gadites: "are your brothers to go to war while you dwell here?" Verses 7-15 are an elaboration on that question, drawing on other biblical texts in order to reinterpret a prior event (the spies story) for the purposes of explaining or teaching something in a new context. They contain an exposition of the presumed intentions and possible consequences of the request made by the Reubenites and Gadites, offering a new theological dimension to the combined narrative.

\section{Conclusions}

After a close examination of the narrative inconsistencies and doublets within Numbers 32 , it appears that there are two internally consistent, coherent, and continuous stories in this chapter as well as a post-compilational insertion that does not affect the narrative of either individual story. This analysis supports a Neo-Documentary model of the composition of the Pentateuch, and provides strong evidence that there was no independent "book" or "scroll" of Numbers as some recent scholars have suggested. ${ }^{63}$ Numbers 32 is not an isolated unit, nor is the book of Numbers a scroll of "proto-midrash" on the rest of the

\footnotetext{
58) Contra Knohl, Sanctuary, 98; Milgrom, Numbers, 493.

59) See the following H texts: Exodus 12:14-20; Leviticus 11:44-45; 16:29-34a; Numbers 9:1-14, 15:1-41, 16:8-11; 17:1-5; 18:1-32; 19:1-22; 27:1-11; 35:1-34.

60) See Numbers $28-29 ; 30 ; 36$.

61) They do, however, look similar to three passages in the book of Joshua: 2:10-12b; 14:7-11; 22:17-18.

62) Van Seters, Life, 443; Loewenstamm, "Settlement," 127; Achenbach, Vollendung, 376-377; Knohl, Sanctuary, 98.

63) See T. Römer, "Israel's Sojourn in the Wilderness and the Construction of the Book of Numbers," in Reflection and Refraction: Studies in Biblical Historiography in Honour of A. Graeme Auld (ed. R. Rezetko, T. H. Lim and W. B. Aucker; Leiden, Boston: Brill, 2007), 444: "as a matter of pure speculation one could even imagine that Deuteronomy was first attached at the end of Leviticus."
} 
Pentateuch. ${ }^{64}$ It is an integral part of the development of the narrative in the Pentateuch as a whole and within its individual sources. Numbers 32 is not "indissoluble," 65 nor can it be explained by the compiler of these narrative strands deviating from his normal practice. ${ }^{66}$ The only abnormality in Numbers 32 is the insertion of vv. 7-15. In every other regard, this chapter is precisely like so many other texts in the Pentateuch: it contains two distinct narratives, each part of and contributing to the narrative progression of a larger independent document within the Pentateuch, in this case E and P.

64) See T. Römer, “Israel's Sojourn," 427.

65) Carpenter and Harford-Battersby, Hexateuch, 239.

66) See n. 3 . 